\title{
Reviewing role of Corporate governance regarding transactions with related parties and company performance among companies admitted into Tehran Stock Exchange
}

\author{
Mehran Matinfard ${ }^{*}, 1$, Mohammad Hassani², Hossein Elyasi ${ }^{3}$
}

1Faculty member Department of Accounting, Islamic Azad University, North Tehran Branch, Tehran, Iran.

mmatinfard@yahoo.com

${ }^{2}$ Faculty member Department of Accounting, Islamic Azad University, North Tehran Branch, Tehran,

Iran.

m_hassani@iau-tnb.ac.ir

${ }^{3}$ The graduates of the master of Accounting, Islamic Azad University, North Tehran Branch, Tehran, Iran.

Hosseinelyasi2@gmail.com

\begin{abstract}
This research reviews the role of corporate governance regarding transactions with related parties and company performance. 85 companies admitted into the TSE were studies during a six months period between 2008 and 2013. Transaction with related parties is a usual trait of commercial activities. For example, some businesses conduct their activities via subsidiary businesses, particular partnerships and related businesses. Transactions with related parties can affect financial situation, financial performance and flexibility of the business. In this research the ratio of non-executive members of the board of directors to total members, membership or non membership of the managing director in the board, size of board and shares of institutional owners have been used as corporate governance variables. Finally, Eviews and Excel software and multi variable regression were used to test the research hypothesis. Results indicate a significant correlation between transactions with related parties and returns on assets. Results also showed that by importing corporate governance variables into the model, explanatory power of model increases and negative effect of transactions with related parties on performance reduces.
\end{abstract}

Keywords: Related parties transactions, financial performance, corporate governance, returns on assets.

* Faculty member Department of Accounting, Islamic Azad University, North Tehran Branch, Tehran, Iran. Email: mmatinfard@yahoo.com 


\section{Introduction}

There are two theories regarding transaction with related parties each of which state different dimension of such transactions:

\subsection{Opportunist theory (Conflict of interests theory):}

Considering theory of conflict of interests, sometimes the incentive for transactions with related parties is that company assets are taken out of company's ownership for the benefit of related parties and manager commits to profit management to cover up.

This theory is consistent with representation and states that such transactions are for personal benefits of managers and causes losses for shareholders and company. However, managers distort financial statements to hide the adverse effects of these transactions (Jiong et al. 2010).

\subsection{Efficient behaviour theory (Efficient Transactions Theory).}

This theory explains that sometimes for reaching experience, unique expertise or skill of related parties or compensation, transaction is conducted with them in which case, there is no motivation for profit management (Gordon \& Henry, 2005).

Corporate governance system is created to provide possibility of control and balance between management and shareholders' interests and consequently, reduction of representation contrast. Therefore, companies with better quality of governance system should face representation contrast less

Our objective is to review the role of corporate governance in transaction with related parties and company performance.

\section{Research theoretical basis: \\ Definition of related party}

According to standard 12 of accounting, related party: a related person is related to the business if and when:

a. Directly or indirectly via one or several intermediates:

1. Control the business, or is controlled by the business, or be under control of unit with it (including main businesses, sub businesses and sub businesses units groups),
2. Has considerable influence in the business or,

3. Controls the business.

b. Business is related to that unit (according to standard 20 of accounting entitled "investment accounting in related businesses"),

c. Be the particular partnership of that unit (according to standard 23 of accounting entitled "particular partnership accounting"),

d. Be main manager of business or be the main business

e. Be close relative of the said parties in clauses "a" or "d",

f.Controlled by said parties in clauses " $\mathrm{d}$ " or " $\mathrm{e}$ ", is jointly controlled by them or under their influence or a significant portion of their voting right is directly or indirectly at their disposal,

g.Pension plan for business employees or pension plan for related parties employees and also businesses to be under the control of such schemes (Iran Accounting Standard, 2007).

\section{Transaction with related parties:}

According to Iran's accounting standard 12 , transaction with related party is defined thus: transfer of resources, services or commitments between related parties, regardless of demand or lack of demand of its value. Ties with related parties can influence financial situation, financial performance and financial flexibility of the business. Related parties may engage in transactions which non related parties don't. The transaction sums between related parties may not be similar to sums in non related parties' transactions. For these reasons, knowledge of transactions, account balance of parties and relation with related parties, may influence financial statements' users' evaluation of business, including risks and opportunities of business (Iran Accounting Standards, 2007).

\section{Corporate governance system:}

The oldest definition for corporate governance is taken from Latin "gubernance" which means guiding a vessel. Definition of corporate governance is very wide. In other words, we can divide this definition to limited view which limits definitions to relation between shareholders and company and wide definition which states the relation between company and other stakeholders including shareholders (Yahya Hassa Biganeh, 2005). 
Elson (2001), defined corporate governance via a view based on financial accounting and financial economy thusly: "corporate governance is a mechanism for solving representation issues. Therefore, coherent and strong corporate governance can positively affect profit quality, reduce incentives and opportunities of profit management and consequently accruals and enhance profit sustainability.

\section{Corporate governance mechanism:}

Ratio of non-bound members of board (composition of board of directors):

composition of the board (a criteria for their independence) as a control tool in company, determines the power of the board. Thus, composition of the board is an important explanatory factor for members' ability to carry out their tasks and help company performance.

a. Size of board of directors: size of board of directors (members) is an important feature in characteristics of the board of directors. Smaller board of directors has less bureaucracy and their insight of financial reporting is probably better.

b. Duality of the CEO's responsibilities: CEO's responsibilities include organising and conducting meetings of the board. In many countries a CEO also acts as the chairman of the board concurrently.

c. Shares owned by institutional owners: shareholders and specially, institutional investors, play a vital role. Institutional investors can supervise company management with their knowledge and sufficient experience in relevant expertise and finance and their influence on management can be the basis for aligning management interests with that of shareholders to maximise shareholders' wealth and on the other hand, allow powerful shareholders' access to confidential information and information asymmetry between powerful shareholders and others.

\section{Research background:}

Rachdi et al. (2004) showed that there is a negative link between company performance and composition of role of board of directors and executive manager because separating their roles bears extra costs such as lack of coordination and weaker decision making which can affect company performance in a reversed way.

Gordon et al. (2004) in their research found that there is a link between transactions with related parties with weak corporate governance mechanism and low market returns. Lawrence \& Caylor $(2004,2006)$ in their research on corporate governance and operational performance showed that companies with 15 to 16 members on their boards had higher dividends and enjoyed a higher net profit margin in comparison to other companies.

Akimova, I. \& G. Schwodianer (2006) reviewed the effect of ownership structure on corporate governance and privatised institutions' performance in the Ukraine and found that ownership has significant influence on performance.

Chien Chu-Yang et al. (2010) reviewed the role of related parties' transactions in company performance and like other researchers, arrived at the negative relation of these two variables. They used accounting quality and non-executive managers as mechanism of corporate governance principles and concluded that these mechanisms can lead to positive relation between related parties' transactions and company performance and reinforce value increase of these transactions.

Baseh et al. (2010) reviewed 1448 companies between 1991-2008 to examine the link between "corporate governance and performance" and concluded that there is no significant correlation between the two.

Chen \& Sou (2010) examined the link between related parties transactions and company performance and also, whether corporate governance positively influences the link between related parties transactions and company performance and used board of directors' independent criterion to measure effect of corporate governance and assumed the effect of related parties' transactions on company performance being affected by corporate governance mechanism. They concluded that there is a negative link between related parties' transactions and company performance. Results showed that corporate governance mechanism changes these transactions from opportunistic to efficient deals and board of directors plays the moderator in these transactions.

Nikbakht \& Rahmani Niya (2010) reviewed effect of board of directors' characteristics including its size, ratio of non executive members in composition of board, number of board meetings and financial knowledge of members and separation of role of executive manager from chairman of board on company performance. Results indicate that the board in Iran's capital market has not carried out its tasks effectively to reduce representation issues and 
has no significant effect on company performance.

Ebrahimi Kurdlur et al. (2010) reviewed the effect of institutional ownership type on company performance. To measure company performance, three indexes (Tobin's $Q$, asset returns and net profit margin) were employed. Results indicated a positive link between institutional ownership and company performance. Also, correlation between various existing institutional investors in company ownership structure and their performance was reviewed by dividing institutional owners into active and passive groups. Findings indicate a positive correlation between both groups (active \& passive) and company performance so it cannot be claimed that activity or passivity of institutions affects their supervisory role.

Zaraee et al. (2012)reviewed the correlation between related parties' transactions and company performance with emphasis on corporate governance variables. Ratio of non executive members of board to total members and membership or non-membership of chairman in board was used as corporate governance variables. Results indicated that there is a significant correlation between related parties' transactions and asset returns. Also, by including corporate governance variables into the model, explanatory power of model increased and negative effect of related parties' transactions on performance was reduced.

\section{Research hypothesis:}

H1: there is a significant correlation between related parties' transactions and performance.

$\mathrm{H} 2$ : corporate governance index effects the relation between related parties' transactions and company performance.

\section{Methodology:}

This research is applied in terms of target and is descriptive and correlated in essence. For analysis of data, the multi linear regression model with panel data and random effects was use. To determine the significance of regression, F statistic was employed.

\section{Statistical sample and community:}

Statistical community included companies admitted into the TSE between 2008 and 2013. Method used for sampling was systematic elimination namely, that companies in the statistical community were selected with consideration of below conditions:
1. Be present in the TSE during the period of research and their shares are dealt in during the same period.

2. Their financial year is not altered during the research period.

3. Have transactions with related parties during research period.

4. Not to be part of investment and financial intermediation companies.

85 companies were identified according to above criteria. The required data was then gathered from information bank at the Tehran Stock Exchange, RahAvard Novin and TadbirPardaz software and TSE publications for the research. Analysis of data was conducted using EViews and Excel software.

\section{Research variables: \\ Independent variables}

RPT: related parties' transactions; considering that information relating to number of transactions, buying and selling with related parties are not revealed by companies accepted into the Tehran Stock Exchange, Rial value of transactions with related parties is used to assess related parties' transactions. Some researchers have recently used total amount earned from related parties' transactions as an index for assessing related parties' transactions (Gordon, 2004; Kohlick and Meyhugh, 2005). However, this criterion will be based on one of the concepts likes book value of assets during homogenisation period or that natural logarithm of related parties' transactions' Rial value will be used.

Corporate governance mechanism are as follow:

1. Ratio of non-executive members of board: for annual corporate observation-companies with higher number of non-executive members to $50 \%$, have a value of 1 and the rest of observations with a value of 0 .

2. Shares of institutional owners: for annual corporate observations-company with 3 institutional shareholders with total share above $50 \%$, the same number and for other observations, value 0 is considered.

3. Size of board of directors: if the number of board members in corporative annual observations-is over 5, it has a value of 1 otherwise, value 0 is given.

4. Duality of managing director's responsibilities: if in corporate annual observation managing director is $\mathrm{CEO}$, value of 1 and otherwise, value 0 is considered.

\section{Dependent variable}

ROA: return on assets; ratio of operational profit after deduction of taxes to assets mean.

Control variables: 
Growth: of assets; ratio of total assets changes to total assets of previous period.

Size: company size; natural logarithm of total assets.

Age: company age; number of years of company activity since foundation to now.

\section{Statistical analysis and test of hypothesis: \\ Results of $\mathrm{H} 1$ test:}

Considering adjusted coefficient of determination obtained for this model which is $60.1 \%$, we can claim that independent and control variables explain over $60 \%$ of dependent variable changes in the research. Also, considering the Watson-Durban statistic of this model which is 1.991, we can claim that first order autocorrelation does not exist among remains of model.

Results of $2^{\text {nd }}$ hypothesis test:

Results of this test with institutional ownership criterion are in table (3).

Considering the adjusted coefficient of determination obtained for this model $(64.6 \%)$, we can claim that control and independent variables explain over $64 \%$ of changes to dependent variable. Also, considering WatsonDurban statistic of this model (1.698), we can claim that first degree autocorrelation does not exist among remains of model.

Results of $2^{\text {nd }}$ hypothesis with board size criterion are in table (4).

Considering the adjusted coefficient of determination obtained for this model $(62.5 \%)$, we can claim that control and independent variables of research explain over $62 \%$ of dependent variable changes. Also, considering Watson-Durban statistic of this model (1.698), we can claim that first degree autocorrelation does not exist among remains of model.

Results of $2^{\text {nd }}$ hypothesis with non-executive members' ratio criterion are in table (5).
Considering the adjusted coefficient of determination obtained for this model $(65.6 \%)$, we can claim that control and independent variables of research $(65 \%)$ explain the changes to dependent variable. Also, considering Watson-Durban statistic of this model (1.698), we can claim that first degree autocorrelation does not exist among remains of model.

Considering the adjusted coefficient of determination obtained for this model (64\%), we can claim that control and independent variables of research (64\%) explain the changes to dependent variable. Also, considering WatsonDurban statistic of this model (1.748), we can claim that first degree autocorrelation does not exist among remains of model.

Result of table (7) presented the result reflect impact of the standard of corporate governance, related party transactions and the relationship between the performance companies listed on the stock exchange.

tables and equations:

\section{Research model:}

The below model is recommended for test of first hypothesis:

$\operatorname{ROA}_{\mathrm{i}, \mathrm{t}}=\beta_{0}+\beta_{1} \mathrm{RPT}_{\mathrm{i}, \mathrm{t}}+\beta_{2} \mathrm{GROW}_{\mathrm{i}, \mathrm{t}}+\beta_{3} \mathrm{SIZE}_{\mathrm{i}, \mathrm{t}}+$ $\beta_{4} \mathrm{Age}_{\mathrm{i}, t}+\varepsilon_{\mathrm{i}, \mathrm{t}}$

Below model is also recommended for test of second hypothesis:

$\mathrm{ROA}_{\mathrm{i}, \mathrm{t}}=\beta_{0}+\beta_{1} \mathrm{RPT}_{\mathrm{i}, \text { }}+\beta_{2} \mathrm{CG}_{\mathrm{i}, \mathrm{t}}+\beta_{3} \mathrm{RPT}_{\mathrm{i}, \mathrm{t}}$ ${ }^{*} \mathrm{CG}_{\mathrm{i}, t}+\beta_{4} \mathrm{GROW}_{\mathrm{i}, \mathrm{t}}+\beta_{5}$ SIZE $_{\mathrm{i}, t}+\beta_{6}$ Age $_{\mathrm{i}, \mathrm{t}}+\varepsilon_{\mathrm{i}}$,

Table 1. Descriptive statistics of research variables

\begin{tabular}{|c|c|c|c|c|c|}
\hline $\begin{array}{c}\text { Standard } \\
\text { Deviation }\end{array}$ & Min. & Max. & Median & Mean & Variables \\
\hline \hline 0.114 & -0.313 & 0.63 & 0.092 & 0.104 & Return on assets \\
\hline \hline 2.6137 & 3.2188 & 19.981 & 11.478 & 11.246 & Related parties' \\
\hline \hline 0.682 & 4.291 & 9.618 & 5.844 & 5.899 & Business Size \\
\hline \hline 0.666 & -0.996 & 3.972 & 0.081 & 0.146 & Company growth \\
\hline \hline 12.118 & 9.0000 & 59.000 & 37 & 35.31 & Company age \\
\hline \hline 4.631 & 0.000 & 19.981 & 11.052 & 9.668 & NXRATIORPT \\
\hline \hline 5.603 & 0.000 & 19.981 & 10.738 & 8.438 & INSOWNRPT \\
\hline \hline 4.781 & 0.000 & 15.5 & 0.000 & 2.543 & DUALITYRPT \\
\hline \hline 3.338 & 0.000 & 18.298 & 0.000 & 1.099 & BSIZERPT \\
\hline \hline
\end{tabular}


Table (2): Results of research model estimation

\begin{tabular}{|c|c|c|c|}
\hline \multicolumn{3}{|c|}{$\mathbf{R O A}_{\mathrm{i}, \mathrm{t}}=\beta_{0}+\beta_{1} \mathrm{RPT}_{\mathrm{i}, \mathrm{t}}+\beta_{2} \mathrm{GROW}_{\mathrm{i}, \mathrm{t}}+\beta_{3} \mathrm{SIZE}_{\mathrm{i}, \mathrm{t}}+\beta_{4} \mathrm{Age}_{\mathrm{i}, \mathrm{t}}+\varepsilon_{\mathrm{i}, \mathrm{t}}$} & \multirow{2}{*}{$\begin{array}{l}\text { Research model } \\
\text { Variables }\end{array}$} \\
\hline Probability of error & T Statistic & Coefficients & \\
\hline 0.000 & 6.473 & 0.494 & Intercept \\
\hline 0.000 & -4.212 & -0.009 & RPTs \\
\hline 0.000 & -5.088 & -0.050 & Business size \\
\hline 0.789 & 0.2674 & 0.0003 & Company age \\
\hline \multirow[t]{6}{*}{0.032} & 2.142 & 0.0118 & Business growth \\
\hline & 0.671 & & $\begin{array}{l}\text { Coefficient of } \\
\text { determination }\end{array}$ \\
\hline & 0.601 & & $\begin{array}{c}\text { Adjusted coefficient } \\
\text { of determination }\end{array}$ \\
\hline & 9.799 & & F statistic \\
\hline & 0.000 & & $\begin{array}{c}\text { Probability of } \mathbf{F} \\
\text { statistic }\end{array}$ \\
\hline & 1.691 & & $\begin{array}{c}\text { Durban-Watson } \\
\text { statistic }\end{array}$ \\
\hline
\end{tabular}

Table 3: Results of research model estimation

\begin{tabular}{|c|c|c|c|}
\hline \multicolumn{3}{|c|}{ 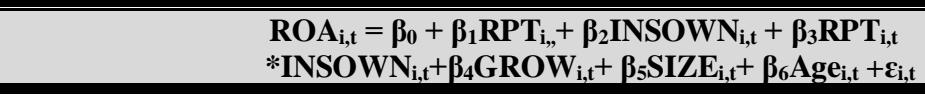 } & \multirow{2}{*}{$\begin{array}{c}\text { Research model } \\
\text { Variables }\end{array}$} \\
\hline Error Probability & T statistic & Coefficients & \\
\hline 0.000 & 5.227 & 0.392 & Intercept \\
\hline 0.000 & -4.765 & -0.012 & RPTs \\
\hline 0.000 & -4.938 & -0.047 & Business size \\
\hline 0.817 & 0.232 & 0.000 & Company age \\
\hline 0.112 & 1.592 & 0.008 & Business \\
\hline 0.001 & 3.499 & 0.095 & Institutional ownership \\
\hline \multirow[t]{6}{*}{0.042} & 2.044 & 0.005 & RPTs and institutional ownership \\
\hline & 0.709 & & Coefficient of determination \\
\hline & 0.646 & & Adjusted determination of coefficient \\
\hline & 11.318 & & F statistic \\
\hline & 0.000 & & Probability of F statistic \\
\hline & 1.698 & & Durban-Watson statistic \\
\hline
\end{tabular}

Table (4): Results of research model estimation

\begin{tabular}{|c|c|c|c|}
\hline \multicolumn{3}{|c|}{$\begin{array}{c}\mathrm{ROA}_{\mathrm{i}, \mathrm{t}}=\beta_{0}+\beta_{1} \mathrm{RPT}_{\mathrm{i}, \mathrm{t}}+\boldsymbol{\beta}_{2} \mathrm{BSIZE}_{\mathrm{i}, \mathrm{t}}+\beta_{3} \mathrm{RPT}_{\mathrm{i}, \mathrm{t}} * \mathrm{BSIZE}_{\mathrm{i}, \mathrm{t}}+\beta_{4} \mathrm{GROW}_{\mathrm{i}, \mathrm{t}}+\beta_{5} \mathrm{Sg} \mathrm{e}_{\mathrm{i}, \mathrm{t}}+\varepsilon_{\mathrm{i}, \mathrm{t}}\end{array}$} & \multirow{2}{*}{$\frac{\text { Research Model }}{\text { Variables }}$} \\
\hline Error Probability & T Statistic & Coefficients & \\
\hline 0.000 & 6.12 & 0.457 & Intercept \\
\hline 0.000 & -4.099 & -0.009 & RPTs \\
\hline 0.000 & -4.75 & -0.046 & Business size \\
\hline 0.805 & 0.248 & 0.000 & Company age \\
\hline 0.035 & 2.115 & 0.011 & Business growth \\
\hline 0.002 & 3.095 & 0.057 & Board of directors' size \\
\hline 0.597 & 0.529 & 0.001 & RPTs and board of directors' size \\
\hline \multicolumn{3}{|c|}{0.691} & Coefficient of determination \\
\hline \multicolumn{3}{|c|}{0.625} & Adjusted coefficient of determination \\
\hline \multicolumn{3}{|c|}{10.413} & F statistic \\
\hline
\end{tabular}




\begin{tabular}{|c|c|c|c|}
\hline \multicolumn{3}{|c|}{0.000} & Probability of F statistic \\
\hline \multicolumn{3}{|c|}{1.640} & Durban-Watson statistic \\
\hline \multicolumn{4}{|c|}{ Table (5): Results of research model estimation } \\
\hline \multicolumn{3}{|c|}{$\begin{array}{l}\text { ROA }_{\mathrm{i}, \mathrm{t}}=\beta_{0}+\beta_{1} \text { RPT }_{\mathrm{i},+}+\beta_{2} \text { NXRATIO }_{\mathrm{i}, \mathrm{t}}+\beta_{3} \mathrm{RPT}_{\mathrm{i}, \mathrm{t}} \\
* \text { NXRATIO }_{\mathrm{i}, \mathrm{t}}+\beta_{4} \mathrm{GROW}_{\mathrm{i}, \mathrm{t}}+\beta_{5} \text { SIZE }_{\mathrm{i}, \mathrm{t}}+\beta_{6} \text { Age }_{\mathrm{i}, \mathrm{t}}+\boldsymbol{\varepsilon}_{\mathrm{i}, \mathrm{t}} \\
\end{array}$} & Research Model \\
\hline Error Probability & T Statistic & Coefficients & Variables \\
\hline 0.000 & 5.574 & 0.411 & Intercept \\
\hline 0.000 & -4.75 & -0.011 & RPTs \\
\hline 0.000 & -5.102 & -0.047 & Business size \\
\hline 0.654 & 0.448 & 0.001 & Company age \\
\hline 0.046 & 2.005 & 0.01 & Business growth \\
\hline 0.013 & 2.5 & 0.043 & Ratio of non-executive members of board \\
\hline 0.01 & 2.586 & 0.004 & RPTs and Ratio of non-executive members of boa \\
\hline \multicolumn{3}{|c|}{0.717} & Coefficient of determination \\
\hline \multicolumn{3}{|c|}{0.656} & Adjusted coefficient of determination \\
\hline \multicolumn{3}{|c|}{11.785} & F statistic \\
\hline \multicolumn{3}{|c|}{0.000} & Probability of F statistic \\
\hline \multicolumn{3}{|c|}{1.722} & Durban-Watson statistic \\
\hline
\end{tabular}

Table (6): Results of research model estimation

\begin{tabular}{|c|c|c|c|}
\hline \multicolumn{3}{|c|}{$\begin{array}{c}\text { ROA }_{\mathrm{i}, \mathrm{t}}=\beta_{0}+\beta_{1} \text { RPT }_{\mathrm{i}, \mathrm{,}}+\underset{\beta_{2} \text { DUALITY }_{\mathrm{i}, \mathrm{t}}+\beta_{3} \mathrm{RPT}_{\mathrm{i}, \mathrm{t}}}{ } * \text { DUALITY }_{\mathrm{i}, \mathrm{t}}+\beta_{4} \text { GROM } \\
\beta_{5} \text { SIZE }_{\mathrm{i}, \mathrm{t}}+\beta_{6} \text { Age }_{\mathrm{i}, \mathrm{t}}+\varepsilon_{\mathrm{i}, \mathrm{t}}\end{array}$} & \multirow[t]{2}{*}{ Research model } \\
\hline Error Probability & T Statistic & Coefficients & \\
\hline 0 & 6.555 & 0.475 & Intercept \\
\hline 0.000 & -3.861 & -0.008 & RPTs \\
\hline 0.000 & -5.238 & -0.049 & Business size \\
\hline 0.857 & -0.181 & 0.000 & Company age \\
\hline 0.006 & 2.739 & 0.014 & Business growth \\
\hline 0.032 & 2.158 & 0.038 & Duality of managing director \\
\hline \multirow[t]{6}{*}{0.027} & 2.223 & 0.004 & $\begin{array}{l}\text { RPTs \& duality of managing } \\
\text { director }\end{array}$ \\
\hline & 0.708 & & Coefficient of determination \\
\hline & 0.646 & & $\begin{array}{c}\text { Adjusted coefficient of } \\
\text { determination }\end{array}$ \\
\hline & 11.328 & & F statistic \\
\hline & 0.000 & & Probability of F statistic \\
\hline & 1.748 & & Durban-Watson statistic \\
\hline
\end{tabular}

Table (7): Results of research model estimation

\begin{tabular}{|c|c|c|c|}
\hline \multicolumn{3}{|c|}{$\begin{array}{c}\text { ROA }_{i, t}=\beta_{0}+\beta_{1} \text { RPT }_{i,,}+\beta_{3} R_{P T} T_{i, t} * G_{i, t}+\beta_{4} G \text { ROW }_{i, t}+\beta_{5} \text { SIZE }_{i, t}+ \\
\beta_{6} \text { ge }_{i, t}+\varepsilon_{i, t}\end{array}$} & \multirow[t]{2}{*}{ Research model } \\
\hline Error Probability & T Statistic & Coefficients & \\
\hline 0.000 & 6.338 & 0.418 & Intercept \\
\hline 0.000 & -7.556 & -0.016 & RPTs \\
\hline 0.000 & -5.117 & -0.043 & Business size \\
\hline 0.829 & -0.215 & -0.0002 & Company age \\
\hline 0.011 & 2.537 & 0.012 & Business growth \\
\hline 0.000 & 6.274 & 0.005 & $\begin{array}{c}\text { RPTs and Ratio of non-executive members of } \\
\text { board }\end{array}$ \\
\hline 0.000 & 6.189 & 0.005 & RPTs \& duality of managing director \\
\hline 0.000 & 5.090 & 0.007 & RPTs and institutional ownership \\
\hline 0.000 & 3.714 & 0.003 & RPTs and board of directors' size \\
\hline \multicolumn{3}{|c|}{0.761} & Coefficient of determination \\
\hline \multicolumn{3}{|c|}{0.708} & Adjusted coefficient of determination \\
\hline
\end{tabular}




\begin{tabular}{|c|c|}
\hline 14.442 & F statistic \\
0.000 & Probability of F statistic \\
1.754 & Durban-Watson statistic \\
\hline \hline
\end{tabular}

\section{Conclusion}

\section{Results of $\mathrm{H1}$ test:}

Results of $\mathrm{H} 1$ test show the existence of a negative and significant correlation between related parties' transactions and company performance. Among control variables, business growth has significant and positive link with performance. Company size variable has significant negative correlation with company performance. Other control variables have significant link with company performance. Results of this research are in line with researches of Chen \& Sou (2010), Choyang Chin et al. (2010) and Gordon et al. (2004).

\section{H2 results with institutional ownership criterion:}

Results of $\mathrm{H} 2$ test with institutional ownership show institutional ownership's significant positive effect on link between RPTs and performance and among control variables, company size has significant negative correlation with company performance. Other control variables have no significant correlation with performance. Results of this research are in line with Lawrence \& Kilver (2006) and contradict results obtained by Akimwa \& Skodianer (2006). $\mathrm{H} 2$ results with board size criterion:

$\mathrm{H} 2$ results with board of directors' size criterion show that board of directors' size variable has not significant effect on relation between related parties' transactions and company performance. Also, board of directors' size variable coefficient is (0.056) and its error level (0.002), this indicates a significant positive correlation between board of directors and company performance. Among control variables, business growth variable has significant positive correlation with performance. Company size variable has significant negative link with company performance. Other control variables have no significant correlation with company performance. Results of this research are in line with Base et al. (2010) and Lawrence \& Kilver (2006).

\section{$\mathrm{H} 2$ results with non-executive board members ratio criterion:}

Results of $\mathrm{H} 2$ test with non-executive board members ratio criterion indicate nonexecutive board members ratio variable has significant positive effect on relation between RPTs and company performance. Also, non- executive board members ratio variable coefficient is (0.043) and error level of (0.012), which means that there is significant positive correlation between non-executive members and performance. Among control variables, company size variable has significant negative link with co. performance. Other control variables have no significant link with company performance. Results of this research are in line with results obtained by Chuyang Chin et al. (2010) and Rachedi et al. (2008).

$\mathrm{H} 2$ results with managing director's duality criterion:

$\mathrm{H} 2$ test results with this criterion show that this managing director's duality variable has significant positive effect on link between related parties' transactions and company performance. Also, duality variable coefficient is (0.032) and error level of (0.032), which indicates a significant positive correlation between managing director's duality and company performance. Among control variables, company size variable has significant negative link with company performance. Other control variables have no significant link with company performance. Results of this research contradict those of Rachedi et al. (2004).

\section{References}

Akimova, I. \& G. Schwodianer, (2006), "Ownership Structure, Corporate Governance and Enterprise Performance: Empirical Result for Ukraine". International Advances in Economic, Vol. 10, 28-42.

Chien, Chu-Yang and Joseph C. S. Hsu (2010). "The Role of Corporate Governance in Related Party Transactions", Working Paper in Developing Practical Prescriptions. British Journal of Management, 16: 91-97.

Elson, C. (2001) “The State of US Corporate Governance: An Interview with Charles Elson", Journal of Applied Corporate Finance, 19(1) 74-80.

Ebrahimi Kurd Lar, Ali, Mohamad Morad and Hoda Skandar, 2010, "Effect of type of institutional ownership on performance of companies admitted into Tehran Stock Exchange 2006 to 2008", 
Audit and accounting research, $2^{\text {nd }}$ year, no. 8, winter, pp. 104-119

Gordon, E. A. and E. Henry (2005). "Related Party Transactions and Earnings Management", Working Paper, Current Draft: November 2005

Hassas Yeganeh, Yahya \& Amir Nasab (2005). Role of institutional investors in corporate governance of jointstock companies, Accountant monthly, nos. 164 \& 165, October \& November 2005.

Iran Standards of Accounting (2007). Standard no. 12, disclosure of related parties' information.

Jian, M, and Wong, T. J. (2010). Earnings Management and Tunneling through Related Party Transactions: Evidence from Chinese Corporate Groups. Retrieved from http://www.bschool.cuhk.ed

hk/research/cig/pdf download/Earnings Management and Tunneling through Related Party. Transactions.pdf

Kohlbeck M. and Brian W. Mayhew, (2010). "Valuation of Firms that Disclose Related Party Transactions", Journal of Accounting and Public Policy, Volume 29, Issue 2, March-April 2010, Pages 115-137

Lawrence D. Brown, Marcus L. Caylor. (2004). Corporate Governance and Firm Performance. Journal of Corporate Finance, 9, 295-316.

Lawrence D. Brown Marcus L. Caylor. 2006. Corporate Governance and Firm Operating Performance. Georgia State University

Nikbakht, Mohamed Reza and Javad Rahmani Nia, 2010, "Review of effect of institutional ownership on performance of TSE companies", Stock Exchange quarterly no. 9, spring, $3^{\text {rd }}$ year, pp. 43-53

Qalibaaf Asl, Hassan \& Rezaee, Fatimeh (2007). "Review of effect of board of directors' composition on performance of TSE companies", Financial Research quarterly, 33:23.

Rachdi, H and Elgaied, M. (2008). Composition, Structure of Board of Directors and Performance: The Case of American Firms, Available at SSRN:http://papers.ssrn.com /sol3/papers.cfm?abstract_id=12094404.
Zaree, Hossein and Esmaeel, Maryam (2012) "Review of relation between profit quality and some initial aspects corporate governance in TSE companies". Audi \& Accounting Review quarterly, no. 45, pp. 25-44 